\title{
CHINA'S SYSTEM OF OPPRESSION IN XINJIANG: HOW IT DEVELOPED AND HOW TO CURB IT
}

\author{
JAMES MILLWARD AND DAHLIA PETERSON
}

SEPTEMBER 2020

\section{EXECUTIVE SUMMARY}

Chinese Communist Party (CCP) policies towards Xinjiang have increased colonial development, further eroded Uyghur autonomy through force and ethnic assimilationism, and co-opted the "Global War on Terror" framing to portray all Uyghur resistance as "terrorism." Since 2016, an intensified regime of technologically-driven mass surveillance, internment, indoctrination, family separation, birth suppression, and forced labor has implicated the provinces and municipalities of eastern China that fund the Xinjiang gulag through the Pairing Assistance Program, as well as potentially thousands of Chinese and international corporations that directly and indirectly supply and benefit from the system.

Today, more than 1,400 Chinese companies are providing facial, voice, and gait recognition capabilities as well as additional tracking tools to the Xinjiang public security and surveillance industry. While a handful of these companies have been placed on the U.S. Department of Commerce's Bureau of Industry and Security's (BIS) Entity List, limiting their access to imported components, this sanctioning has not yet significantly arrested these companies' development. While it is infeasible to sanction every company operating in or associated with Xinjiang, it is still of great concern that many companies have evaded scrutiny and continue to perpetuate oppression today. Furthermore, Western companies continue to sell Chinese firms core hardware such as chips and storage solutions, for which China currently lacks viable homegrown alternatives.
To meet these challenges and increase public awareness, we provide a slate of policy recommendations for the United States, its allies, and China. These include that the United States' messaging strategy must more clearly articulate the intended aims of its policy actions on Xinjiang, including but not limited to the closure of its internment camps, the reduction of surveillance, and the elimination of "pre-criminal" profiling of Xinjiang's indigenous peoples. The Uyghur Human Rights Policy Act of 2020 and the Tariff Act of 1930 should be resolutely applied to address forced labor and other repression. BIS and the State Department, along with academics, researchers, and NGOs, should publicly report on Chinese surveillance companies' supply chains to close alternative solutions loopholes and increase corporate due diligence. Candidates for the Entity List should also be informed by a public repository of rights abuses in Xinjiang and beyond. To achieve these goals, State Department-run Track 1 dialogues and the newly formed Inter-Parliamentary Alliance on China (IPAC) and Global Partnership on Al (GPAI) should also develop an allied set of principles and goals for countering the global expansion of China's surveillance approach, as well as proposing alternative surveillance technology standards at the United Nations' International Telecommunications Union. U.S. allies should strengthen refugee and cultural protection for Uyghurs, and apply sanctions to responsible entities and individuals. 


\section{HISTORY}

Although the current crisis in Xinjiang is the immediate product of People's Republic of China (PRC) policies in the 21st century, the longer term history of Qing imperial and Chinese Nationalist rule as well as earlier decades of CCP rule over the region offer instructive contrasts to - as well as some continuities with recent approaches to governing China's Central Asian region.

\section{Qing and Chinese Nationalist rule in Xinjiang}

For millennia, the region now called Xinjiang was a focus of Central Asian geopolitical struggle as well as a conduit for trans-Eurasian trade, cultural exchange, and migration. The Qing empire conquered the region in 1758 and controlled it through a pluralist system with ethnic elites administering co-ethnics. In its last decades, the Qing attempted to colonize parts of Xinjiang with Han Chinese, but this effort failed and most of the Han farmers returned east.

The Chinese Nationalist government (KMT) first gained a foothold in the region in the early 1940s. It promulgated its own ambitious plans to colonize Xinjiang with one million Chinese refugees (the region's indigenous population was under 4 million). ${ }^{1}$ Such schemes were impossible for the hard-pressed Nationalists to implement, and with few Han in Xinjiang, the KMT granted representation and considerable local autonomy to indigenous Xinjiang groups, while sharing power in the region overall with the Sovietsponsored Eastern Turkestan Republic (ETR) based in northern Xinjiang.

\section{PRC acquisition and administration of Xinjiang}

In the summer of 1949, KMT forces surrendered southern Xinjiang to the People's Liberation Army (PLA). After the leadership of the ETR died in a mysterious plane crash en route to Beijing, the CCP appointed a new cadre of Turkic officials, who renounced East Turkestan autonomy. The PRC resettled 80,000 KMT troops as the Xinjiang Production Construction Corps (XPCC) or Bingtuan (兵团) and recruited women from east China cities to marry them and put down roots in Xinjiang. Supported by massive subsidies from Beijing, the Bingtuan became Xinjiang's primary colonial institution, resettling millions of Han beginning in the 1950s, building Han enclaves throughout the region, and running state farms, industrial enterprises, labor camps, prisons, and now "educational transformation" camps. $^{2}$ That the proportion of Han in Xinjiang has grown from a few percent in 1949 to equal or outnumber indigenous Uyghurs and other Central Asian peoples is largely due to the efforts of the Bingtuan. The XPCC has developed a portfolio of global assets with over 800,000 majority and minority shell company holdings. ${ }^{3}$ The XPCC security bureau and some of its top leaders were sanctioned by the U.S. Treasury Department in $\mathbf{2 0 2 0}$ for its role in internment camps and forced labor - if stringently enforced, this could limit the outsized and discriminatory role of this organization in Xinjiang's economic development. ${ }^{4}$

Following Qing and Soviet precedents, the PRC implemented ethno-pluralist policies in Xinjiang under its system of 56 minzu (民族, "nationalities" or ethnic groups). In 1955 Xinjiang was designated the Xinjiang Uygur Autonomous Region (XUAR). However, autonomy has always been symbolic, and Han party officials in fact control the region, under direction from the CCP, backed up by police, the paramilitary People's Armed Police and, as necessary, the PLA. Ironically, the Handominated Bingtuan is the only somewhat autonomous political unit in the Uygur Autonomous Region, as it is only nominally subject to the XUAR while in practice handling its own administrative and judicial affairs and answering directly only to Beijing. ${ }^{5}$

Despite its Potemkin qualities, the minzu system functioned relatively well in Xinjiang for the first decades of the PRC. Arguments suggesting Muslim Central Asians will automatically resist Chinese rule are not borne out by PRC history. What serious disruptions occurred in the region resulted from disastrous policies such as the Great Leap Forward and the Cultural Revolution. During the latter, it was the Bingtuan and rusticated Han youth from eastern Chinese cities who occasioned unrest, more than the Uyghurs.

In the 1980s, the modest liberalization that followed the Cultural Revolution ushered in what some Uyghurs now wryly consider a golden age for Xinjiang's non-Han peoples. Indigenous representation in government 
and party increased somewhat, and non-Han cultural production flourished. As tensions with the Soviet Union abated, trade with Central Asia expanded. No longer viewing Xinjiang simply as a strategic buffer against possible Soviet invasion, the PRC began investing more substantially in the region's urban and transport infrastructure.

Liberalization in Xinjiang affected Xinjiang people as it did those elsewhere in China: just as Han students in eastern China took advantage of this relaxation to demonstrate over social and political issues, so did Uyghur students in Xinjiang. However, discontent in Xinjiang was labeled "separatist" and "pan-Turkic," as well as "counter-revolutionary."

In 1990, an attempted uprising in the small town of Baren evoked a region-wide state response, the first of an ongoing series of "Strike Hard" campaigns that have recurred sporadically from the 1990s through the most recent iteration in 2014. These waves of repression are characterized by house searches, religious restrictions, mass arrests, and executions. In 1997, authorities violently put down a large demonstration in Ghulja protesting the illegalization of popular Uyghur social clubs. Thereafter, through 2008 the region was generally quiet. ${ }^{6}$

\section{Branding indigenous unrest as "terrorism"}

However, during this quiet period, Chinese state and international media began to amplify the narrative of growing Islamic threat. Following the September 11, 2001 attacks in the United States, the PRC employed the Bush administration's rhetoric to situate Uyghur unrest within the "Global War on Terror," despite lack of evidence of large-scale organization behind, or international involvement in, incidents in the Uyghur region. In an apparent bid to court PRC support for a United Nations resolution justifying the U.S. invasion of Iraq, the United States in 2002 problematically designated the "East Turkestan Islamic Movement" (ETIM) an international terrorist organization, a move that we and other analysts think was incorrect based on the facts. In the designation statement, the U.S. State Department quoted PRC propaganda, while attributing to ETIM a list of acts that not even the PRC had blamed on the previously unknown group, which had never had a presence in China. ${ }^{7}$
Thereafter the false notion took root that ETIM was a substantial, organized international group responsible for violent acts in Xinjiang. Many terrorism analysts have continued to repeat this mistaken conventional wisdom, though ETIM effectively disappeared in $2003 .{ }^{8}$ For example, a line in one recent Brookings paper is untrue in key respects: "China has long faced low-level violence from the East Turkestan Islamic Movement (ETIM), which seeks an independent Xinjiang." ${ }^{\circ}$ Lowlevel violence, yes, but not from the ETIM, which has never been active in or even had a presence within Xinjiang. Nor can we confidently connect Xinjiang's ongoing low-level violence with desire for independence - we simply do not have reliable information on the motives of those behind the unrest, most of which involves clashes with police and state offices.

After the U.S. and U.N. designations of ETIM, "Uyghur terrorism" became a constant drumbeat. Fears voiced in PRC and global media that Uyghur terrorists would attack the 2008 Beijing Olympics were not borne out, although there were attacks on police and military units in Xinjiang around that time. The July 5, 2009 race riots in Xinjiang's capital Ürümqi, though labeled "terrorist" by Chinese authorities, in fact erupted because armed police forcefully repressed a peaceful protest by Uyghurs demanding an investigation into the lynching of two Uyghurs in a Guangdong factory several days earlier. Official PRC statistics mention only the nearly 200 Han killed on July 5, not the many Uyghurs killed by live fire from police and military and at the hands of Han vigilantes over the next two days. Hundreds or thousands more Uyghurs were detained over subsequent days and weeks.

The first incidents since the $1990 \mathrm{~s}^{10}$ that clearly involved premeditated Uyghur political violence against civilians were a vehicular attack and self-immolation in Beijing in October 2013, a mass knifing at the Kunming railway station in March 2014, a knife and bomb attack at the Ürümqi train station in April 2014, and a vehicular and explosives attack on an Ürümqi market in May 2014. These events marked the long-predicted advent in Xinjiang and China of jihadi tactics. There is, however, little evidence of organization beyond the small numbers of attackers themselves or of coordination with any group outside of China. Besides these unambiguous incidents of terrorism, in the 2010s there were more frequent clashes between Uyghurs and security forces 
during riots, at state offices, or inside Uyghur homes as police ostensibly searched for extremists and enforced the state prohibition on veils. ${ }^{11}$ In some of these incidents, the deaths of Uyghur so-called terrorists far outnumbered other casualties. PRC sources describe all such unrest as terrorism, but it is important to distinguish growing unrest - some of it violent, against increasingly repressive policies of a regime reneging on constitutional promises of autonomy - from the four acts of civilian-targeted violence in 2013-14.

\section{The PRC measures go far beyond constraints on religion, to target the Uyghur language itself and arbitrarily incarcerate intellectual elites and Uyghur party members who are patently secular.}

A recent influential article by Sheena Chestnut Greitens, Myunghee Lee, and Emir Yazici suggests that the hightech surveillance, mass political indoctrination in internment camps, and coerced labor in Xinjiang have been motivated primarily by PRC state perception of a terrorist threat, both arising from religious "extremism" of Muslim Turkic people at home, and seeping back into Xinjiang from abroad like an infection. ${ }^{12}$ As will be seen below, the PRC measures go far beyond constraints on religion, to target the Uyghur language itself and arbitrarily incarcerate intellectual elites and Uyghur party members who are patently secular. Thus the idea that top CCP leaders themselves believe they are responding to a jihadi threat is questionable. In any case, whether fear of religious extremism is a genuine PRC perception or propaganda, one of us (Millward) argues that it is a mistake to discuss Xinjiang with PRC interlocutors under the rubric of "counterterrorism" as Greitens, Lee, and Yazici suggest. To do so would perpetuate the original U.S. mistake of the 2002 ETIM designation, and risk once again confining our understanding of the Xinjiang crisis within the subjective and myopic frame of "terrorism." The "infectious thought virus" from which people may be coercively "inoculated" is a dangerous Orwellian metaphor, not a realistic security analysis, and U.S. and international commentators and governments should not validate it.
Rather, we should discuss the broader reasons for Uyghur dissatisfaction and unrest, which has sporadically erupted into violence against police and official targets as well as in the four terrorist incidents of 2013-14. Though the PRC labels all unrest as religiously motivated "terrorism," that is a misdiagnosis of the problem. ${ }^{13}$

\section{CRISIS}

\section{Development and assimilationism}

Space here does not permit a full historical examination of PRC policies in Xinjiang leading to the crisis of the late 2010s. However, the crisis, which some have called ethnocide, cultural genocide, or even genocide, ${ }^{14}$ may be broadly understood as the convergence and culmination of failed development policies, ${ }^{15}$ increasingly aggressive assimilationist policies, and a cycle of repression-resistance-repression that has played out in Xinjiang since the 1990s.

Although development efforts have featured in the PRC's Xinjiang policies for decades, since the start of the 21st century, two campaign-style programs have amplified these efforts. With the Great Development of the West (西部大开发), launched in 2000, Beijing invested in major transportation and economic projects, stressing cotton and oil, then Xinjiang's most lucrative products. This western development program largely bypassed Uyghurs and the local economy, and it did not achieve its stated goals of stimulating local growth or narrowing the economic gap between the eastern and western parts of the country. ${ }^{16}$

In the aftermath of the 2009 violence, Xinjiang and central authorities greatly expanded an existing program, the Pairing Assistance Program (对口支 援新疆), by requiring 19 eastern provinces and municipalities to devote $0.3-0.6 \%$ of annual revenues to development in a Xinjiang sister-city, and to dispatch personnel as advisers. Yuhui Li's study concludes that the Pairing Assistance Program resulted in a flurry of top-down, capital-intensive projects, especially industrial parks and latch-key commercial development zones, chosen to suit the industrial needs of the eastern Chinese partners, and often ill-suited to local economic conditions. Over-capacity and ghost towns resulted. ${ }^{17}$ The Pairing Assistance Program's relatively 
minor investment in human development prioritized Chinese-language instruction (teaching Uyghurs to teach Mandarin), a sensitive issue that resonated with contemporary sinicization policies, including the razing of the old city of Kashgar and state opposition to veiling, public prayer, and fasting at Ramadan. ${ }^{18}$

\section{Mass, technologically-enabled repression of Xinjiang indigenous peoples}

In May 2014, then-Xinjiang Party Secretary Zhang Chunxian revived "Strike Hard" and inaugurated the "People's War on Terror" in the region. A "Xinjiang Work Forum" that same year enshrined "stability maintenance" as the centerpiece of Xinjiang policies, displacing the prior goal of economic development. By that point, hacker groups connected to the state were in full swing, targeting Uyghur mobile users around the world for mass real-time surveillance. ${ }^{19}$ A new counterterrorism law (December 2015), a "de-extremification" ordinance (March 2017), and a revision of the regulations governing religions affairs (September 2017) provided new, often vaguely worded, justifications for detaining and punishing Uyghurs, Kazakhs, Kyrgyz, and other Muslims based on symbols and practices related to Islamic belief and other behavior.

From 2017, CCP policy trajectories of colonial development and ethnic assimilation converged dramatically in a repressive program implemented on an unprecedented scale by the new Xinjiang Party Secretary, Chen Quanguo, who had been transferred to the region from Tibet in 2016. While the record of new laws and regulations since 2014 or earlier suggests that Chen's arrival in Xinjiang in August 2016 was not the sole catalyst for the heightened repression that began in 2017, he presided over its material implementation against the intensified legal and regulatory backdrop. In his first year in Xinjiang, Chen hired 100,000 new security personnel and built thousands of "Convenience Police Stations" to implement grid policing. ${ }^{20}$ Chen's Xinjiang supplemented conventional police methods with facial recognition video, cell phone inspection software, remote cell phone tracking and sniffing (remote data collection), and the gathering of personal information (banking, travel, social media, religious practice) as well as biometric data. The biodata, collected in the course of mandatory medical examinations and in the process of issuing ID cards, included DNA, blood type, face-scan, retinal scan, voice-print and gait-print.

In principle, all data is entered into the Integrated Joint Military Operations Platform (IJOP, 一体化联合 作战平台), ${ }^{21}$ made by a subsidiary of the state-owned defense conglomerate China Electronics Technology Company (CETC). The IJOP uses algorithms to predict the likelihood of "extremism" in individuals and sort them for imprisonment, indoctrination, or surveillance, and legitimizes computational racism by punishing the entire Uyghur ethnic group for behaviors and beliefs deemed suspicious by authorities. Such behavior includes insufficient socialization with neighbors, avoiding the front door, having more than two children, or having foreign contacts. ${ }^{22}$ The extent of the IJOP's influence was revealed in late 2019 when the International Consortium of Investigative Journalists (ICIJ) obtained classified Chinese documents, including four "bulletins" from June 2017 on how the IJOP surveils Xinjiang residents and those who became foreign nationals for monitoring, indoctrination, or detention based on purported threats of "terrorism" and "extremism." These terms are never defined in the documents. ${ }^{23}$

In one week in June 2017, for example, the system flagged 24,421 "suspicious persons" in Kashgar, Khotan, Kizilsu, and Aksu districts and prefectures; 706 of these were arrested as criminals; 15,683 were sent to the "concentrated educational transformation" camps (see below); and 2,096 were put under "preventive surveillance." 24 Authorities also used material discovered on smartphones or sent in previous years via WeChat to justify internments. The introduction of $3 G$ networks and smartphones in Xinjiang from the early 2010s had allowed convenient exchange of images, voice memos, and video and audio clips, including on religious topics. The subsequent state deployment of technology that could transcribe Uyghur speech and then search the transcripts for keywords deemed extremist, such as "Quran" or "Allah," provided pretexts for interning or imprisoning people for their thoughts. ${ }^{25}$ In 2017 and 2018, more than 350,000 people were prosecuted through the legal system in Xinjiang, while in previous years, the figure had been less than 30,000 annually." 26 
In addition to the approximately tenfold increase of the prison population, Chen expanded so-called “concentrated educational transformation" (集中 教育转化), a program previously forced upon drug addicts, problem children, Falun Gong practitioners and, in Xinjiang, some young men with beards and women who chose to wear certain head and facial coverings. Starting in the spring of 2017, Xinjiang authorities began detaining 5-15\% of the Muslim population across Xinjiang, more in the south, and more men than women, within a vastly scaled up reeducation system. To manage such numbers, Xinjiang administrative units and Bingtuan settlements called for private corporate bids to build and outfit dozens of large internment camps surrounded by high walls, barbed wire and guard towers, and secured inside with locked cells, locked corridors, and ubiquitous video surveillance. $^{27}$

According to leaked documents and first-person accounts, these Xinjiang internment camps provided at least three levels of confinement, from reformschool to prison conditions, and interned more than one million people. ${ }^{28}$ New kindergartens and orphanages for the children of detainees went up in a parallel construction boom. ${ }^{29}$ It is not known how many remain in the camps or to what extent new internees are being confined. There have also been reports of prisoner transfers from Xinjiang to Sichuan and Gansu provinces as well as China's northeast. ${ }^{30}$

Uyghur, Kazakh, Kyrgyz, and Uzbek internees have not been tried before internment, but simply accused of extremism. Signs of supposed extremism, published in a list used by police for the purpose of identifying "precrimes" in potential internees, include such mundane Islamic practices as avoiding alcohol, fasting, veiling, wearing a beard, or owning a Quran. Foreign travel or contacts and having "too many children" are also justifications for detention. ${ }^{31}$ Within the camps, internees are subjected to regimented daily routines, political indoctrination, some Mandarin language training, and forced renunciations of Islam and Uyghur culture. Former detainees who have managed to leave China report crowded cells, unsanitary conditions, poor food, beatings, physical and psychological torture, and systematic rape, as well as forced sterilization, IUD-implantation, and administration of anti-fertility drugs. ${ }^{32}$
Although PRC authorities insist that the camps are "vocational training centers," a leaked template for design and running of the camps signed by Zhu Hailun, Chen's deputy party chief and security tsar in Xinjiang, specifies that "students" must complete at least one year of "concentrated educational transformation" and pass a strict evaluation of their political thinking and discipline before they proceed to a further three to six months of "vocational" training that actually involves factory skills. ${ }^{33}$ Whatever vocational training internees are given, then, only takes place after their release from the camps.

From the latter half of 2018 , some internees began to be assigned to work in factories located within the internment camps, transferred to "satellite factories" near poor villages in southern Xinjiang, transferred to factories in industrial parks or Bingtuan settlements in various parts of Xinjiang, or transferred to factories in eastern parts of China. And this is how CCP policy trajectories of colonial development and ethnic assimilation converged: many of the factories to which internees have been assigned are those constructed and run by the XPCC or by eastern Chinese provinces, cities, and companies under the Pairing Assistance Program. ${ }^{34}$ The former internees were sometimes not paid, or were paid low wages. The numbers involved are substantial: in 2018 Kashgar prefecture alone announced plans to transfer 100,000 workers from the camps to industrial parks and village satellite factories, where they would manufacture textiles and garments for companies receiving government subsidies for employing them. This pattern was repeated across Xinjiang and elsewhere in China. ${ }^{35}$

Researchers for the Australian Strategic Policy Institute (ASPI) identified 27 factories in nine Chinese provinces employing transferred Uyghur workers either directly from the camps or after completion of non-confinement political education programs. Some of these factories are outfitted like prisons, with walls and guard towers, and officially labeled "semi-military." Workers are required to attend political study and Chinese classes and are denied freedom of movement outside of dormitories or immediate factory precincts. ${ }^{36}$

Prolonged confinement in camps and involuntary labor transfer has broken up families. Women and older people in Uyghur villages, too, have been employed 
in satellite factories under regimented conditions. Children whom they would traditionally have cared for at home are now housed in Mandarin-language boarding kindergartens and primary schools. ${ }^{37}$

\section{4 \\ The extensive linkages of Xinjiang and other Chinese factories employing Uyghur labor to Chinese and foreign suppliers mean that global supply chains are already extensively tainted by the internment camp and forced labor regime, especially in the textile industry.}

While official PRC statements describe these programs as "poverty alleviation," 38 in a situation where more than a million people have been extra-legally confined in internment camps, none of these work assignments can be considered voluntary, and in cases may amount to slave labor. The extensive linkages of Xinjiang and other Chinese factories employing Uyghur labor to Chinese and foreign suppliers mean that global supply chains are already extensively tainted by the internment camp and forced labor regime, especially in the textile industry. Xinjiang produces between a fifth and a quarter of the world's cotton, depending on the year, much of it on Bingtuan farms. ${ }^{39}$ Xinjiang cotton is mixed with cotton from elsewhere in yarn, fabric, and garments. The ASPI researchers connected forced Uyghur labor to 83 well-known global brands, including Nike, Adidas, Fila, BMW, Mitsubishi, Panasonic, Huawei, The North Face, H\&M, and Victoria's Secret. ${ }^{40}$ In July 2020, the U.S. Commerce Department added a subsidiary of the Hong Kong-based Esquel Group, one of the world's largest shirt-makers, to the BIS Entity List. Esquel maintained a partnership with the XPCC until April 2020, and in summer 2020 was still running three factories in Xinjiang. ${ }^{41}$

\section{Surveillance companies involved}

Chinese and non-Chinese companies alike are involved in Xinjiang's system of surveillance, implicating them in the forms of repression mentioned above. These companies benefited financially and reputationally in 2015 from the central government's policy of prioritizing "stability" in Xinjiang and the construction of the national rural-focused Sharp Eyes surveillance program. ${ }^{42}$ By 2018 , nearly 1,400 Chinese companies were competing for lucrative contracts in Xinjiang - of these, around 1,000 were Xinjiang-based. ${ }^{43}$

From the perspective of policy options, these companies fall into three groups: Chinese companies that have landed on the BIS Entity List for their harms to human rights in Xinjiang; active Chinese players in Xinjiang that have so far evaded U.S. sanction; and Western companies selling core hardware to either of the two preceding groups.

\section{Entity List companies and impact}

In October 2019, the United States began to use human rights to justify adding Chinese companies and government bodies to the BIS Entity List in order to cut off these entities' access to imported components. Many offending Chinese companies, however, remain unlisted. ${ }^{44}$ BIS selected eight companies and 20 Xinjiang government institutions, including the XPCC's Public Security Bureau, pointing to their "implementation of China's campaign of repression, mass arbitrary detention, and high-technology surveillance" against Uyghurs, Kazakhs, and other Turkic Muslim groups in Xinjiang. ${ }^{45}$ The list included video surveillance companies Dahua, Hikvision, Megvii, Yitu, Sensetime, and Yixin Science and Technology Co. Ltd, voice recognition firm iFlytek, and digital forensics firm Xiamen Meiya Pico Information Co. Ltd. ${ }^{46}$ The role these companies play in Xinjiang will be discussed below.

In May 2020, BIS added eight more Chinese companies and China's Ministry of Public Security's Institute of Forensic Science to the list under the same justification. ${ }^{47}$ The additions included Aksu Huafu Textiles, likely due to forced labor concerns, facial recognition companies CloudWalk, Intellifusion, IS'Vision, NetPosa and its subsidiary SenseNets, and IT infrastructure company FiberHome Technologies Group, along with its cloud and big data subsidiary Nanjing FiberHome Starrysky Communication Development. ${ }^{48}$ 
Many of the sanctioned Chinese companies are also on the Chinese Ministry of Science and Technology's national "Al Champions" list. ${ }^{49} \mathrm{Al}$ champions have a voice in national technical standards setting, relative freedom from competition with state-owned enterprises, and are meant to help China lead the world in $\mathrm{Al}$ technologies by $2030 .^{50}$ Of the 15 national champions, five have been placed on the Entity List for human rights violations in Xinjiang: iFlytek, Hikvision, Yitu, Megvii, and SenseTime.

China's facial recognition giants form the backbone of its surveillance system in Xinjiang and exercise great influence across China and the globe. Hikvision and Dahua supply around one-third of the global market for security cameras and related goods like digital video recorders. ${ }^{51}$ From 2016 to 2017, 11 Hikvision and Dahua Public-Private Partnership Safe Cities and public security checkpoint projects in Xinjiang totaled more than 7 billion yuan ( $\$ 1.2$ billion). ${ }^{52}$ One Hikvision project in of Ürümqi was worth $\$ 79$ million, with a network of 30,000 security cameras, video analytics hubs, intelligent monitoring systems, big data centers, police checkpoints, and drones. ${ }^{53}$ Another Hikvision project in Pishan County included the installation of a surveillance system in a re-education camp and mosques. ${ }^{54}$

Unlike other facial recognition companies on the Entity List, state-owned CETC has controlled Hikvision since its inception and enjoyed "substantial fiscal subsidies." ${ }^{55}$ Hikvision has worked closely with CETC to expand and maintain the IJOP in Xinjiang (originally developed by another CETC subsidiary). ${ }^{56}$ Hikvision had also won a bid to build the second stage of the IJOP, including WiFi sniffers to track the unique addresses of networked devices and allow cameras to track people via personal electronics. ${ }^{57}$

Facial recognition companies, such as Yitu, Cloudwalk, and Intellifusion, actively market their products for public security use. At "anti-terrorism" expos held in Xinjiang in August 2017, CloudWalk demonstrated its Fire Eye (火眼) product, capable of 24-hour monitoring and immediate police notification upon detection of fugitives or persons of interest. 58 At the same expos, Intellifusion demonstrated Deep Eye (深目), purportedly customizable for anti-terrorism needs. ${ }^{59}$ Yitu launched a similar project called Dragonfly Eye (蜻
蜓眼), capable of performing static photo-based face comparisons or video-based dynamic comparisons in both residential and public areas. ${ }^{60}$ All of the abovementioned companies' products could be used to identify subjects of interest among the Uyghur population, referred to by the authorities as "focus personnel." ${ }^{1}$

Beyond facial recognition, longtime voice recognition player iFlytek collaborated with hardware and service providers Meiya Pico and Fiberhome to develop tools automating transcription and translation of Uyghur language audio into Mandarin. This product enables authorities to scan for "pre-criminal" and criminal content. ${ }^{62}$ After iFlytek established a subsidiary and laboratory in Xinjiang to develop speech recognition technology focusing on non-Chinese languages, authorities in the region adopted the tool for tracking and identifying non-Han populations. ${ }^{63}$

\section{Limited impact of Entity List designation}

Placement on the Entity List has not yet significantly slowed the development of these companies, as they have claimed to source supply chain alternatives and have received renewed demand under COVID-19. Following the October 2019 BIS decision, Hikvision and Dahua stated that, while hardware such as central processing units (CPUs), graphics processing units (GPUs), and field-programmable gate arrays (FPGAs) will be difficult to replace, the vast majority of American components can be substituted, with little or no impact on product performance. ${ }^{64}$ iFlytek said it will boost research and development efforts given technology tensions between the United States and China. ${ }^{65}$

One might argue, however, that goal of placement on the Entity List is not simply to restrict companies' access to U.S. technology. The BIS listing of a subsidiary of the Esquel Group, a behemoth shirt-maker which supplies the world's most famous fashion labels, sent shock waves through the global garment industry. The fact that Esquel unwound its long term joint venture with Bingtuan subsidiary White Field Farming by May 2020 suggests that it had already recognized the liability of association with the XPCC before being listed. ${ }^{66}$ It remains to be seen whether BIS listings can have a similar effect on technology companies less reliant 
on brand names and consumer sales, and whether Esquel or other companies can shift to sourcing robotics manufacturing tools from non-U.S. sources. ${ }^{67}$

\section{Non-Entity List companies' influence}

Several technology companies not yet placed on the Entity List have perpetuated both overt and indirect human rights harms in Xinjiang. Longtime Xinjiangbased Leon Technology, for example, oversaw half of the Safe City projects in Ürümqi by the end of 2017.68 The firm also launched a joint venture with SenseTime called Tang Li Technology, increasing surveillance through "convenience police stations" in Kashgar and expanding monitoring to thousands of video access points in the city's rural areas. ${ }^{69}$

Data doors, manufactured by companies such as Pingtech, CETC, and Dilusense, have also been integral to data collection efforts in Xinjiang. ${ }^{70}$ Resembling walk-through metal detectors, these smart entryways have facial recognition capabilities and ID card verification, and can lift electronic device identifier numbers such as MAC addresses and IMEI, IMSI, and ESN numbers; who builds them and how they source their components is often unclear. ${ }^{71}$ When collected data is combined with data from facial recognition, surveillance cameras, license plates, phone records, and social media posts, authorities can track individuals with alarming clarity. ${ }^{72}$

\section{Western companies' role}

An under-examined question is how Western companies have bolstered China's surveillance state and Xinjiang operations through investment and/ or financing, academic and research partnerships, intellectual property transfer, medical equipment export for surveillance (as in the case of Thermo Fisher), or hardware exports. ${ }^{73}$ These firms provide a technical basis for China's unprecedented mass racial profiling and ethnic oppression, especially in hardware, as Chinese companies largely cannot provide homegrown substitutions and rely on the West for the chips that enable deep learning and storage hard drives designed for surveillance. ${ }^{74}$

American companies such as Intel, NVIDIA, Xilinx, Seagate, and Western Digital have sold hardware used in Chinese surveillance operations. ${ }^{75}$ According to Chinese sources, GPUs from Intel and NVIDIA have delivered direct benefits to Chinese surveillance companies. ${ }^{76}$ Hikvision and Dahua both rely on these chips for their servers, cameras, and safe city applications. ${ }^{77}$ Hikvision and Dahua also depend on leading American hard drive companies such as Seagate and Western Digital; Chengdu Xiwu Xinan, a company active in Xinjiang, stated that it only uses Western Digital and Seagate's products. ${ }^{78}$

It is also possible that NVIDIA and Intel hardware have contributed to detection of Uyghurs in video surveillance systems outside of Xinjiang, as at least eight nationwide Ministry of Public Security (MPS) projects require NVIDIA and Intel chips to perform Uyghur detection. ${ }^{79}$ The MPS mandated this capability in its December 2017 draft facial recognition guidelines - which were met by Hikvision, Yitu, Megvii, SenseTime, and CloudWalk. ${ }^{80}$

\section{CONCLUSIONS AND RECOMMENDATIONS}

Viewed against the backdrop of 70 years of PRC rule, the heightened oppression in Xinjiang since 2016 can be seen as both continuation of and departure from earlier CCP policies. Colonialist and assimilationist tendencies underlay the earliest PRC and even Chinese Nationalist rule. They are now greatly intensified, as even official sources shift from a narrative of ethnic pluralism in favor of a patently Han-centric vision of a homogeneous China. But what is new, beyond just the extremity of the policies, is the degree to which what happens in Xinjiang is no longer just about Xinjiang: the massive, technologically-sophisticated systems of surveillance, internment, and involuntary labor are linked to the rest of China through the Pairing Assistance Program, and to myriad Chinese and international companies through webs of supply and investment.

After two years of ambivalence, U.S. President Donald Trump's signature of the Uyghur Human Rights Policy Act of 2020 has belatedly allowed the Xinjiang issue its proper place in U.S.-China relations. The Trump administration's previously self-contradictory China policies arguably led many countries worldwide to remain largely silent on the Xinjiang crisis. Some countries have even expressed support for PRC policies 
in Xinjiang, owing to their economic interdependence with China, hope for Belt and Road Initiative-related loans or aid, their own poor human rights records, and their adherence - shared with China - to so-called "non-interference in internal affairs." Thirty-six states backed China in the U.N. Human Rights Council in response to a critical 2019 letter by 22 democratic nations calling out the Xinjiang atrocities. ${ }^{81}$ However, with U.S. denunciation of the Xinjiang repression now forthright and enjoying bipartisan domestic support, there is renewed hope for creating a concerted allied strategy with clearly articulated goals to address this issue, through parallel and possibly joint actions.

Below, we offer relevant policy recommendations for the United States, other global and multilateral actors, and the Chinese authorities.

\section{Policy recommendations for the United States related to surveillance technology}

1. State Department-run Track 1 dialogues, the newly formed Inter-Parliamentary Alliance on China (IPAC) and the Global Partnership on AI (GPAI) can develop an allied set of principles and goals to understand countries' surveillance adoption drivers, and counter the global expansion of China's surveillance apparatus with democratically-driven alternatives. This coordination would advance the IPAC's goals of upholding human rights and strengthening security, and the GPAl's goals of responsible development and use of $\mathrm{Al}$ grounded in human rights. ${ }^{82}$ Alternative surveillance technology standards can be proposed at the U.N.'s International Telecommunications Union, where Chinese companies have been the only submitters since 2016, and therefore the only major player shifting normative goalposts. ${ }^{83}$

2. BIS and the State Department, along with academics, researchers, and NGOs, should publicly disclose knowledge of Chinese surveillance companies' supply chains, and determine how many suppliers are from the U.S. and other democracies. This would help determine if, how, and from where companies on the Entity List are finding alternative solutions, and assist with companies' export due diligence.
3. The above-mentioned groups should create a public repository of rights abuses in Xinjiang, modeled off databases such as the California Proposition 65 list or the Environmental Protection Agency's Toxics Release Inventory (TRI) Program, to further scrutinize and identify underexamined companies for the Entity List. ${ }^{84}$ For instance, Chinese video surveillance company Uniview's president told reporters that, at a time when "leading Chinese technology companies are facing tough scrutiny overseas," companies such as Uniview had the opportunity to grow and pursue their global strategies. ${ }^{85}$

4. Utilizing the above knowledge, the State Department should compare its draft guidance for surveillance technology exports with other democracies' approaches, and discuss where to advance its guidance. ${ }^{86}$ Relevant bodies include the 42-member Wassenaar Arrangement. ${ }^{87}$

5. Congress should prevent Chinese surveillance companies from selling their technology in the United States, beyond current bans on use by U.S. government customers, as in the case of Hikvision and Dahua. Closing a significant market would reduce these companies' abilities to plow profits into research and development and slow progress toward alternative hardware solutions for firms on the Entity List. Congress should additionally pass the Foreign Advanced Technology Surveillance Accountability Act of 2020 , which would document the use of excessive surveillance to violate human rights in annual State Department country reports on human rights practices. ${ }^{88}$

6. BIS and the interagency process should disclose if the earlier inclusion of Huawei on the Entity List has arrested its surveillance activities in Xinjiang, even if that was not why Huawei was initially sanctioned. For example, Huawei reportedly built the police surveillance systems in Karamay and Kashgar prefectures, and was praised by the head of Xinjiang provincial police department for its contributions to the "Safe Xinjiang" program. ${ }^{89}$ 
General policy recommendations for the United States regarding repression of Uyghurs and other Xinjiang indigenous peoples

1. The United States should more clearly articulate the intended aims of its policy actions on Xinjiang to include the closure of internment camps; reduction of surveillance and elimination of "pre-criminal" profiling of Xinjiang indigenous peoples; an end to family separation and birth suppression targeted at Uyghurs and other nonHan groups; return to previous PRC support and promotion of the identity and culture of Xinjiang's non-Han groups; and encouragement of a Xinjiang economic development program prioritizing indigenous conditions and human rights.

2. The U.S. Citizenship and Immigration Services (USCIS) should address its asylum backlog for the hundreds of Uyghurs settled in the United States who face deportation risk and nearcertain internment if returned to China. This logjam is especially prevalent at the Arlington, Virginia, USCIS service center, which processes applications in the region where most Uyghurs have settled. ${ }^{90}$

3. The United States should enhance its position to advocate for human rights and fair economic practices in Xinjiang and the PRC more broadly by joining and/or re-energizing its role in AsiaPacific regional multilateral organizations and meetings (TPP, APEC, ASEAN), and by rejoining the U.N. Human Rights Council. This will add more collective weight to U.S. remonstrances regarding PRC practices, provide support to other states who might hesitate to speak out about PRC rights abuses or expose complicit corporations without U.S. and regional backing, and counter PRC influence in these bodies.

4. The Labor Department's Bureau of International Labor Affairs (BILA) should prioritize investigating and publicizing the Xinjiang issue and be provided with requisite funding to do so. ${ }^{91}$ The BILA should investigate not only Xinjiangbased factories, but commercial and carceral operations of the Bingtuan; Xinjiang-related activities of Chinese municipalities, provinces and corporations involved in the Pairing Assistance Program; and other arrangements by which the PRC state channels Xinjiang labor into manufacturing. The BILA should publish and frequently update lists of goods and enterprises of concern.

5. Potential U.S. importers of goods from China should strengthen their due diligence in scrutinizing supply chains for involvement in the Xinjlang surveillance, internment, and involuntary labor complex. Many importer and third party supply-chain audits have proven unreliable. ${ }^{92}$ The potential for brand tainting by association with Xinjiang repression is high, even for firms relying on suppliers based in other parts of China. ${ }^{93}$ Where possible, firms should demand full information about Chinese supply chains from raw material to consumer product, and outsource audits less to third-party audit firms in favor of personal site-visits. Trade organizations should invest in emerging technologies that allow tracing of materials through DNA, microbial, blockchain, and other tagging methods. Consumers should demand transparent sourcing of products from China, and exercise caution regarding products from or associated indirectly with the XUAR or the 19 provinces and municipalities in the Partner Assistance Program. ${ }^{94}$

6. U.S. Customs and Border Protection (CBP), as informed by the BILA and private actors, should robustly enforce forced labor restrictions to block imports of goods associated with the Xinjiang surveillance, internment, and involuntary labor complex. CBP should take as a rebuttable presumption that Xinjiang-related manufactures, those produced with Uyghur labor in factories outside of Xinjiang, and goods produced by firms supplied indirectly by Xinjiang-related enterprises, especially the XPCC, use forced labor as defined in Section 307 of the Tariff Act of 1930. Challenges to CBP "withhold release" orders that proceed as far as the U.S. Court of International Trade should be treated as opportunities to further publicize the issue. 
7. The president of the United States, secretary of state, Federal Bureau of Investigation, and director of national intelligence should thoroughly fulfill reporting and implementation provisions of the Uyghur Human Rights Policy Act of 2020 (P.L. 116-145). ${ }^{95}$ In determining the list of "foreign persons" deemed responsible for repression of Xinjiang indigenous peoples, the President should continue to scrutinize officials in XUAR party and administration and in the Bingtuan, as well as officials of other Chinese municipalities and provinces involved in the Pairing Assistance Program, and key officers of companies linked to the Xinjiang surveillance, internment. and forced labor complex. Congressional committees concerned with foreign affairs, finance, and intelligence should pay close attention to the reports they are scheduled to receive according to the act.

\section{Policy recommendations for global and multilateral actors}

1. Other nations should coordinate with the United States to identify, publicize, and sanction officials and corporations associated with the repression in Xinjiang. Chinese and international corporations should redouble their diligence efforts to avoid direct or indirect association with the Xinjiang surveillance, internment, and forced labor complex. All nations should denounce the repressive policies in Xinjiang during interactions with PRC interlocutors.

2. All nations should provide asylum and support to ethnic Uyghurs, Kazakhs, Kyrgyz, and other Xinjiang indigenous peoples fleeing oppression in the PRC, in adherence to the principle of nonrefoulement.

3. The United Nations Educational, Scientific and Cultural Organization (UNESCO) should investigate whether the PRC is adequately fulfilling its obligations as a party to the Convention for the Safeguarding of Intangible Cultural Heritage in regard to Meshrep and Muqam, both inscribed on the Intangible Cultural Heritage list. ${ }^{96}$
4. Corporations and nations should signal to PRC authorities that their sponsorship and participation in the 2022 Beijing Olympics will be impossible if the current treatment of Xinjiang peoples continues. Where possible, these démarches should be issued collectively.

Policy recommendations for the People's Republic of China and authorities in the Xinjiang Uygur Autonomous Region

To avoid further damage to China's international standing and to the Xinjiang economy, and to minimize the risk of future instability, the PRC and Xinjiang authorities should:

1. Immediately curtail practices of internment, psychological and physical abuse including "concentrated educational transformation" (集中教育转化), family separation, birth suppression, and involuntary labor in Xinjiang. Reduce levels of surveillance targeting nonHan peoples; allow Uyghurs and other non-Han peoples freedom of movement within the PRC; end discrimination in housing and the use of the hukou registration system to restrict freedom of movement and residence for Uyghurs and other non-Han peoples; restore free use of the spoken and written Uyghur language in public settings; and return to earlier PRC policies that celebrated the diversity of the country's ethnic groups.

2. Implement a development program sensitive to the needs of Uyghurs and other Xinjiang peoples. In lieu of capital-intensive construction projects or coercive efforts to turn farmers en masse into lowwage factory workers, implement best-practice development strategies such as microfinancing to encourage small-scale entrepreneurship among Uyghurs, based on principles of individual, family, and local autonomy. End labor and credit systems in southern Xinjiang that force Uyghur farmers into conditions of debt servitude. ${ }^{97}$

3. Desegregate, break up, and reform the Bingtuan (XPCC). Eliminate its discriminatory hiring and residential practices; cease recruiting migrants from eastern China to Xinjiang while simultaneously transferring Uyghurs out of Xinjiang 
to eastern China. Subsidies now given to Bingtuan recruits and residents should be reallocated towards environmentally sound development benefiting local people. The involvement of the Bingtuan in prisons, extralegal internment camps, and involuntary labor has tainted its agricultural, industrial, and commercial enterprises, along with the Chinese and foreign companies with which they do business, such as the Esquel Group. This stain will continue to damage Xinjiang's economic prospects as long as the XPCC, now 85\% Han, remains segregated and dedicated to developing Xinjiang for the primary benefit of Han and the central PRC government. The XPCC's carceral and security activities should be divested from its economic activities, and the remaining network of enterprises broken up and reformed to staunch fiscal waste and encourage local non-Han involvement. 


\section{REFERENCES}

1 James Millward, Eurasian Crossroads: A History of Xinjiang (New York: Columbia University Press, 2007), 212.

2 Bingtuan recruitment ads appear frequently on Xinjiang job websites such as “事业单位招聘考试网” [Work unit recruitment exam net], http://www.shiyebian.net/xinjiang/. For example, there were 19 Bingtuan listings on the Sheyebian website on September 4, 2020, archived at https://web.archive.org/save/http://www.shiyebian. net/xinjiang/.

3 Alex Bate, “U.S.-Sanctioned Xinjiang Paramilitary Has Over 800,000 Holdings Worldwide," Sayari, August 4, 2020, https://sayari.com/blog/u-s-sanctioned-xinjiang-paramilitary-has-over-800000-holdings-worldwide/. On Bingtuan historical and current involvement in forced labor at all tiers of the cotton apparel industry, see Amy Lehr, "Addressing Forced Labor in the Xinjiang Uyghur Autonomous Region: Toward a Shared Agenda," (Washington, DC: Center for Strategic and International Studies, July 30, 2020) https://www.csis.org/analysis/ addressing-forced-labor-xinjiang-uyghur-autonomous-region-toward-shared-agenda.

4 "Treasury Sanctions Chinese Entity and Officials Pursuant to Global Magnitsky Human Rights Executive Order," U.S. Department of the Treasury, July 31, 2020, https://home.treasury.gov/news/press-releases/sm1073; Bethany Allen-Ebrahimian, “U.S. sanctions China's paramilitary in Xinjiang," Axios, July 31, 2020, https://www. axios.com/us-sanctions-china-paramilitary-xinjiang-xpcc-41e29c92-9649-4e47-9e91-a7f78330d4d8.html.

5 Bao Yajun, "The Xinjiang Production Construction Corps: An Insider's Perspective," originally published online in January 2018 as part of the University of Oxford's Blavatnik School of Government's working papers series (BSG-WP-2018/023). A significantly altered version was published as Bao Yajun, "The Xinjiang Production and Construction Corps: An Insiders Perspective," China: An International Journal 18, no. 2 (May 2020): 161-174, https://muse.jhu.edu/article/756368. The journal-published version lacks some of the specific data included in the original. It states that the Bingtuan was restored in 1981 (after being dissolved during the Cultural Revolution) "due partly to the rise of the Islamic Resistance Movement in Afghanistan" (163), a reference to Islam and Afghanistan which Bao did not make in the original version. The 2020 version cuts Bao's discussion of the degree to which Bingtuan recruitment of Han Chinese from eastern China is directly subsidized by the central government and elides his note that "in recent years" $90 \%$ of the XPCC budget consists of central government financial support” (16), a figure which underscores how Beijing uses the Bingtuan, despite its vast economic inefficiencies, to promote Han settler colonialism in Xinjiang. The original 2018 version, removed in summer 2020 from the University of Oxford website, has now been republished on Academic.edu: https://www.academia. edu/44022879/Bao Yajun The Xinjiang Production and Construction Corps An Insiders Perspective. Millward can also provide a copy of the 2018 version to interested scholars who inquire at millwarj@georgetown. edu.

6 On the PRC regime and its 1990s policies see Gardner Bovingdon, The Uyghurs: Strangers in Their Own Land (New York: Columbia University Press, 2010) and James Millward, Eurasian Crossroads, chapters 6-7. On the Bingtuan, see Tom Cliff, Oil and Water: Being Han in Xinjiang (Chicago: University of Chicago Press, 2016) and Greg Fay, The Bingtuan: China's Paramilitary Colonizing Force in East Turkestan (Washington, DC: Uyghur Human Rights Project, April 2018), https://docs.uhrp.org/pdf/bingtuan.pdf. On the background to the 1997 Ghulja incident, see Jay Dautcher, Down a Narrow Road: Identity and Masculinity in a Uyghur Community in Xinjiang China (Cambridge, MA: Harvard University Press, 2009).

7 On the argument that the designation of ETIM was meant to court PRC support for U.N. Security Council Resolution 1441 justifying the George W. Bush administration's invasion of Iraq, see Erik Eckholm, “U.S. Labeling of Group in China as Terrorist Is Criticized," The New York Times, September 13, 2002, https://www.nytimes. com/2002/09/13/world/us-labeling-of-group-in-china-as-terrorist-is-criticized.html; James Dao, "THREATS AND RESPONSES: DIPLOMACY; Closer Ties With China May Help U.S. on Iraq," The New York Times, October 4, 2002, https://www.nytimes.com/2002/10/04/world/threats-and-responses-diplomacy-closer-ties-with-china-may-helpus-on-iraq.html; Karen DeYoung, "U.S. and China Ask U.N. to List Separatists as Terror Group," The Washington 
Post, September 11, 2002, https://www.washingtonpost.com/archive/politics/2002/09/11/us-and-china-askun-to-list-separatists-as-terror-group/a3adaa3e-2cd3-4861-b544-eac800757255/. A State Department official speaking on background with one of the authors (Millward) in late 2002 confirmed that the ETIM designation was part of the campaign to gain PRC support. ETIM was a small group based in Afghanistan, previously unknown to most Xinjiang specialists. The PRC had included ETIM in a white paper cataloging a number of "'East Turkistan' terrorist forces" and alleging that these forces had committed 200 terrorist attacks, causing 162 deaths and over 440 injuries, between 1990 and 2001, although the document actually described many fewer incidents and the death and casualty tolls of events described in the document do not add up to these totals. The white paper associated few acts with specific named groups, and did not allege that ETIM was responsible for any of the acts. See State Council Information Office, People's Republic of China, “'East Turkistan' Terrorist Forces Cannot Get Away With Impunity," Embassy of the People's Republic of China in the United States of America, January 21, 2002, http://www.china-embassy.org/eng/xw/t34101.htm. However, the U.S. State Department statement designating ETIM a terrorist group attributed all 200 attacks, 162 deaths, and 440 injuries to ETIM - and thus the idea of an organized, international, and deadly Uyghur terrorist organization was born. See Philip P. Pan, “U.S. Warns Of Plot by Group in W. China," The Washington Post, August 29, 2002, https://www.washingtonpost. com/archive/politics/2002/08/29/us-warns-of-plot-by-group-in-w-china/5607dd9b-9d70-419a-8bac-

1f3b39e12bc9/. The PRC language, as mis-copied by the U.S. statement, was subsequently reiterated in the U.N. designation of ETIM as a terrorist group. "Press Statement on the UN Designation of The Eastern Turkistan Islamic Movement," U.S. Department of the Treasury, September 12, 2002, https://www.treasury.gov/press-center/ press-releases/pages/po3415.aspx. See James Millward, Eurasian Crossroads, 340, and Sean R. Roberts, The War on the Uyghurs: China's Internal Campaign against a Muslim Minority (Princeton, NJ: Princeton University Press, 2020), 78-80. Earlier studies must be treated with extreme caution, if not entirely discounted, as many are based on the original uncorroborated PRC white paper or the mistaken State Department statement.

8 Sean R. Roberts, The War on the Uyghurs, 85-86, 141. See also Sean R. Roberts, "China's hidden partner in suppressing the Muslim Uighurs - the US," The Guardian, June 24, 2020, https://www.theguardian.com/ commentisfree/2020/iun/24/china-suppressing-muslim-uighurs-us-trump-9-11.

9 Daniel L. Byman and Israa Saber, "Is China prepared for global terrorism? Xinjiang and beyond," (Washington, DC: The Brookings Institution, September 2019), https://www.brookings.edu/research/is-china-prepared-forglobal-terrorism/.

10 In 1992 and 1997 there were bus bombings in Ürümqi about which we know little.

11 In 2011, Xinjiang authorities launched "Project Beauty," a campaign discouraging veils, hijab, and other kinds of face and hair coverings worn by Uighur women. In 2015, the standing committee of the Ürümqi People's Congress illegalized clothing "items that mask the face or robe the body in public places." Timothy Grose, "Beautifying Uyghur Bodies: Fashion, 'Modernity', and State Power in the Tarim Basin," The Contemporary China Centre Blog, University of Westminster, October 11, 2019, http://blog.westminster.ac.uk/contemporarychina/ beautifying-uyghur-bodies-fashion-modernity-and-state-power-in-the-tarim-basin-2/.

12 Sheena Chestnut Greitens, Myunghee Lee, and Emir Yazici, "Counterterrorism and Preventive Repression: China's Changing Strategy in Xinjiang," International Security 44, no. 3 (Winter 2019/2020): 9-47, https://www. mitpressjournals.org/doi/abs/10.1162/isec a 00368. Sean R. Roberts in The War on the Uyghurs, published after Greitens, Lee, and Yazici's article, shows that the ETIM of the early 2000s and the Uyghurs who fled Xinjiang from 2010 were unconnected organizationally. Uyghurs who had been active in Syria whom Roberts interviewed had never heard of ETIM. Roberts also argues that the few thousand Uyghurs in Syria, many of them women and children, were extremely unlikely to return to China; he does acknowledge, however, that fear of their potential may be common among Chinese people generally and within the state bureaucracy below those highest levels privy to the best intelligence. Sean R. Roberts, The War on the Uyghurs, 196-197.

13 Sean R. Roberts, "China's hidden partner in suppressing the Muslim Uighurs - the US." Roberts provides full background and documentation underlying this essay in his book, The War on the Uyghurs. 
14 James Leibold, "China's treatment of Uighurs is cultural genocide," Asia Times, July 28, 2019, https:// asiatimes.com/2019/07/chinas-treatment-of-uighurs-is-cultural-genocide/; Editorial, "What's happening in Xinjiang is genocide," The Washington Post, July 6, 2020, https://www.washingtonpost.com/opinions/globalopinions/whats-happening-in-xinjiang-is-genocide/2020/07/06/cde3f9da-bfaa-11ea-9fdd-b7ac6b051dc8 story.html.

15 Xinjiang has among the lowest average incomes, lowest life expectancy, and highest infant and maternal mortality rates of any place in China (maternal mortality rates in 2014 were five times the PRC national average, second only to Tibet). Southern Xinjiang, and other places where the Uyghur population is densest, is far poorer than the Xinjiang average. Ethnicity (Han or non-Han) is the strongest predictor of health outcomes: the greater the Han population in a locale, the better the outcomes. Yuhui Li, China's Assistance Program in Xinjiang: A Sociological Analysis (New York: Lexington Books, 2018), 103-06. Regarding the failures of development, see also Ilham Tohti, "Present-Day Ethnic Problems in Xinjiang Uighur Autonomous Region: Overview and Recommendations," trans. Cindy Carter, Ilham Tohti Initiative, September 2016, https://ilhamtohtisite.files. wordpress.com/2016/09/ilham-tohti present-day-ethnic-problems-in-xinjiang-uighur-autonomous-regionoverview-and-recommendations complete-translation3.pdf. Regarding intensified securitization and assimilative policies, see Darren Byler, "Spirit Breaking: Uyghur Dispossession, Culture Work and Terror Capitalism in a Chinese Global City," (PhD diss., University of Washington, 2018), https://digital.lib.washington.edu/ researchworks/bitstream/handle/1773/42946/Byler washington 0250E 19242.pdf; David Tobin, Securing China's Northwest Frontier: Identity and Insecurity in Xinjiang (Cambridge, UK: Cambridge University Press, 2020). Regarding Uyghur birthrate suppression, see "China cuts Uighur births with IUDs, abortion, sterilization," Associated Press, June 29, 2020, https://apnews.com/269b3de1af34e17c1941a514f78d764c; Adrian Zenz, "Sterilizations, IUDs, and Mandatory Birth Control: The CCP's Campaign to Suppress Uyghur Birthrates in Xinjiang," (Washington, DC: The Jamestown Foundation, June 2020), https://jamestown.org/product/ sterilizations-iuds-and-mandatory-birth-control-the-ccps-campaign-to-suppress-uyghur-birthrates-in-xinjiang/.

16 Yuhui Li, China's Assistance Program in Xinjiang: A Sociological Analysis (New York: Lexington Books, 2018), 132-33.

17 Agence France-Presse, "Ghost cities haunt stability dream in China's far west," South China Morning Post, September 4, 2017, https://www.scmp.com/news/china/economy/article/2109555/ghost-cities-hauntstability-dream-chinas-far-west.

18 Yuhui Li, China's Assistance Program in Xinjiang, especially 134-39.

19 Paul Mozur and Nicole Perlroth, "China's Software Stalked Uighurs Earlier and More Widely, Researchers Learn," The New York Times, July 1, 2020, https://www.nytimes.com/2020/07/01/technology/china-uighurshackers-malware-hackers-smartphones.html.

20 Adrian Zenz and James Leibold, "Securitizing Xinjiang: Police Recruitment, Informal Policing and Ethnic Minority Co-optation," The China Quarterly 242, no. (June 2020), https://www.cambridge.org/core/journals/ china-quarterly/article/securitizing-xinjiang-police-recruitment-informal-policing-and-ethnic-minority-cooptation/ FEEC613414AA33A0353949F9B791E733; James Leibold, "Surveillance in China's Xinjiang Region: Ethnic Sorting, Coercion, and Inducement," Journal of Contemporary China 29, no. 121 (2020), https://www. tandfonline.com/doi/full/10.1080/10670564.2019.1621529.

21 Although usually translated as "Integrated Joint Operations Platform," the Chinese term specifies 作 战， i.e. war-making or military operations. It is significant that the system feeding "students" into the so-called vocational training program is designated a military system created by a defense conglomerate.

22 Bethany Allen-Ebrahimian, "Exposed: China's Operating Manuals for Mass Internment and Arrest by Algorithm," International Consortium of Investigative Journalists, November 24, 2019, https://www.icij.org/ investigations/china-cables/exposed-chinas-operating-manuals-for-mass-internment-and-arrest-by-algorithm/. 
An IJOP bulletin instructed officials that "if it is not possible at the moment to eliminate suspicion, it is necessary to put [the suspect] in concentrated training and further screen and review." Scilla Alecci, "How China Targets Uighurs ‘One by One' for Using a Mobile App," International Consortium of Investigative Journalists, November 24, 2019, https://www.icij.org/investigations/china-cables/how-china-targets-uighurs-one-byone-for-using-a-mobile-app/. See also Maya Wang, "China's Algorithms of Repression: Reverse Engineering a Xinjiang Police Mass Surveillance App," (New York: Human Rights Watch, May 1, 2019), https://www. hrw.org/ report/2019/05/02/chinas-algorithms-repression/reverse-engineering-xinjiang-police-mass.

23 Bethany Allen-Ebrahimian, “Exposed: China's Operating Manuals for Mass Internment and Arrest by Algorithm."

24 “'Integrated Joint Operations Platform' Daily Essentials Bulletin No. 14," Integrated Joint Military Operations Platform, June 25, 2017, https://www.documentcloud.org/documents/6558506-China-Cables-IJOP-DailyBulletin-14-English.html. Document published by International Consortium of Investigative Journalists as part of "The China Cables," https://www.icij.org/investigations/china-cables/. Original Chinese version: https://www. documentcloud.org/documents/6558505-China-Cables-IJOP-Daily-Bulletin-14-Chinese.html.

25 Darren Byler, "Spirit Breaking," 47.

26 Emily Feng, “'Illegal Superstition': China Jails Muslims For Practicing Islam, Relatives Say,” NPR, October 8, 2019, https://www.npr.org/2019/10/08/764153179/china-has-begun-moving-xinjiang-muslim-detaineesto-formal-prisons-relatives-say. Data drawn from the PRC and Xinjiang statistical yearbooks, court records, and other sources. Given the 99\% conviction rate in Chinese courts, we can assume that 300,000 additional prosecutions equates to approximately 300,000 more convicts in prison.

27 Adrian Zenz, “'Thoroughly reforming them towards a healthy heart attitude': China's political re-education campaign in Xinjiang," Central Asian Survey 38, no. 1 (September 2018), 102-128, https://www.tandfonline. com/doi/full/10.1080/02634937.2018.1507997.

28 Adrian Zenz calculated the initial estimates of numbers interned on the basis of camp size, local quotas, and Chinese documents. Ibid. In February 2018, a Uyghur activist media outlet in Turkey released a document it says was leaked by a "believable member of the security services on the ground" in Xinjiang. The document, dating from late 2017 or early 2018, tabulates precise numbers of internees in county-level detention centers, amounting to 892,329 (it excluded municipal-level administrative units, notably the large cities of Ürümqi, Khotan, and Yining). Naoko Mizutani “水谷尚子, “ウイグル絶望収容所の収監者数は89万人以上” [" [The number of internees in Uyghur despair camps exceeds 890,000], Newsweek Japan, March 13, 2018, https:// www.newsweekjapan.jp/stories/world/2018/03/89-3 1.php. Though the document's provenance cannot be confirmed, if genuine it supports the estimates of a million or more total internees. Randall Schriver, then assistant secretary of defense for Indo-Pacific Security Affairs at the U.S. Department of Defense, estimated that up to three million Xinjiang Muslims were interned in the camps. Phil Stewart, "China putting minority Muslims in 'concentration camps,' U.S. says," Reuters, May 3, 2019, https://www.reuters.com/article/us-usachina-concentrationcamps/china-putting-minority-muslims-in-concentration-camps-us-says-idUSKCN1S925K. These figures and figures quoted in media accounts generally do not include over 300,000 newly put in prison in 2017-2018, though they are also victims of the algorithm-aided round-up of supposed extremists. Shawn Zhang and other researchers gathered further evidence of the internment system's scale from satellite images and coordinates from Google Earth and other open sources. Journalists were able to confirm the identification of sites as internment camps by visiting some of them on the ground. See Shawn Zhang, "List of Re-education Camps in Xinjiang 新疆再教育集中营列表," Medium, May 20, 2018, https://medium.com/@shawnwzhang/listof-re-education-camps-in-xinjiang-\%E6\%96\%B0\%E7\%96\%86\%E5\%86\%8D\%E6\%95\%99\%E8\%82\%B2\%E9\%9B\% 86\%E4\%B8\%AD\%E8\%90\%A5\%E5\%88\%97\%E8\%A1\%A8-99720372419c; Shawn Zhang, "Xinjiang Re-education Camps List by Cities," Medium, May 20, 2019, https://medium.com/@shawnwzhang/xinjiang-re-educationcamps-list-by-cities-f4ed0a6e095a; and other photo essays posted on by Zhang on Medium, https://medium. com/@shawnwzhang. A more extensive BuzzFeed News investigation identified through satelite imagery 268 
compounds with prison features built since 2017 in Xinjiang and through other sources verified 92 of these as detention centers. Megha Rajagapolan, Alison Killing, and Christo Buschek, "China Secretly Built A Vast New Infrastructure To Imprison Muslims," BuzzFeed News, August 27, 2020, https://www.buzzfeednews.com/article/ meghara/china-new-internment-camps-xinjiang-uighurs-muslims.

29 Nicole Bozorgmir and Isobel Yeung, "Uighur Parents Say China Is Ripping Their Children Away and Brainwashing Them," Vice, July 1, 2019, https://www.vice.com/en us/article/7xgj5y/these-uighur-parents-saychina-is-ripping-their-children-away-and-brainwashing-them. Official statistics for Khotan (Hotan) prefecture show an abrupt increase from approximately 400 kindergartens in 2011-2016 to approximately 1,200 in 2017.

30 "Xinjiang Authorities Secretly Transferring Uyghur Detainees to Jails Throughout China," Radio Free Asia, October 2, 2018, https://www.rfa.org/english/news/uyghur/transfer-10022018171100.html. One of the authors (Millward) received an account written by a witness to the arrival in Sichuan of a bus caravan of prisoners from Xinjiang.

31 For more on the punishments for having "too many" children, see "China cuts Uighur births with IUDs, abortion, sterilization," Associated Press.

32 Maya Wang, “'Eradicating Ideological Viruses',” (New York: Human Rights Watch, September 9, 2018), https://www.hrw.org/report/2018/09/09/eradicating-ideological-viruses/chinas-campaign-repressionagainst-xinjiangs; "China cuts Uighur births with IUDs, abortion, sterilization," Associated Press; Adrian Zenz, "Sterilizations, IUDs, and Mandatory Birth Control."

33 Zhu Hailun, "Opinion on further strengthening and standardizing vocational skills education and training centers work," Autonomous Region State Organ Telegram, 2017, https://www.documentcloud.org/ documents/6558510-China-Cables-Telegram-English.html. Document published by International Consortium of Investigative Journalists as part of "The China Cables." Original Chinese version: https://www.documentcloud. org/documents/6558509-China-Cables-Telegram-Chinese.html.

34 The Pairing Assistance Program and techno-oppressive surveillance / internment / forced labor system are thoroughly intermeshed. The first cases of Western companies reported to be relying on Uyghur forced labor, Badger Sportswear and Costco, were found to be supplying from factories in a new industrial park built by Beijing in Khotan (Hetian) under the Pairing Assistance Program and run by the Chinese firm Hetian Taida. Juozapas Bagdonas, "Tracking Down the Fruits of Xinjiang's Forced Labor Industry," The Diplomat, November 16, 2019, https://thediplomat.com/2019/11/tracking-down-the-fruits-of-xinjiangs-forced-labor-industry/. The website of the Xinjiang Uygur Autonomous Region Development and Reform Commission boasted on December 5, 2019 that "with vocational skill educational training centers [i.e. internment camps] as the vehicle, [our policies] have attracted a large number of coastal enterprises from eastern China to invest and build factories, which has powerfully expanded employment and promoted income growth.” “自治区经济结构稳中有活 发 展良好" [The economic structures of the Autonomous Region are lively within stability and development is excellent], 新疆维吾尔自治区发展和改革委员会 [Xinjiang Uygur Autonomous Region Development and Reform Commission], December 5, 2018, https://web.archive.org/web/20190520143306/http:/www.xidrc.gov.cn/ info/9923/23516.htm. Adrian Zenz compiles voluminous evidence of the connections between the Pairing Assistance Program and the surveillance / internment / forced labor system in Xinjiang. Adrian Zenz, "Beyond the Camps: Beijing's Long-Term Scheme of Coercive Labor, Poverty Alleviation and Social Control in Xinjiang," Journal of Political Risk 7, no. 12 (December 2019), https://www.jpolrisk.com/beyond-the-camps-beijings-longterm-scheme-of-coercive-labor-poverty-alleviation-and-social-control-in-xinjiang/.

35 “喀什地区困难群体就业培训工作实施方案” [Implementation program for Kashgar region impoverished groups' employment and job training], August 7, 2018, https://web.archive.org/web/20181204024839/http:// kashi.gov.cn/Government/PubliclnfoShow.aspx?ID=2963, cited in Adrian Zenz, "Beyond the Camps," 9. 
36 Vicky Xiuzhong Xu, Danielle Cave, James Leibold, Kelsey Munro, and Nathan Ruser, "Uyghurs for sale: 'Reeducation', forced labour and surveillance beyond Xinjiang," (Barton, Australia: Australian Strategic Policy Institute, March 1, 2020), https://www.aspi.org.au/report/uyghurs-sale.

37 Adrian Zenz, “Beyond the Camps," 17.

38 For example, "Path to Prosperity: Localized factories lift Xinjiang locals out of poverty," CGTN, May 8, 2020, https://news.cgtn.com/news/2020-05-08/Localized-factories-lift-Xinjiang-locals-out-of-poverty-OkbViBZI60/index. $\underline{\mathrm{html}}$.

39 Global cotton production has ranged between 25 and 27 million tons in recent years. China produced 5.9 million tons in 2019, and "more than 5 million" tons were grown in Xinjiang, 89\% of China's total. "Top 10 Cotton Producing Countries in the World," Discover Natural Fibres Initiative, July 1, 2020, https://dnfi.org/cotton/top10-cotton-producing-countries-in-the-world 4785/; Mao Weihua and Zheng Caixioing, "Xinjiang still China's largest cotton producer in 2019," China Daily, January 8, 2020, https://www.chinadaily.com.cn/a/202001/08/ WS5e156c70a310cf3e3558336b.html.

40 Vicky Xiuzhong Xu, Danielle Cave, James Leibold, Kelsey Munro, and Nathan Ruser, "Uyghurs for sale"; Eva Dou and Chao Deng, "Western Companies Get Tangled in China's Muslim Clampdown," The Wall Street Journal, May 16, 2019, https://www.wsj.com/articles/western-companies-get-tangled-in-chinas-muslim-clampdown-11558017472. As the authors completed drafting this article, the Caterpillar corporation was reported to be selling clothing made with Xinjiang forced labor. Bethany Allen-Ebrahimian, "Exclusive: Caterpillar sourced clothes from Xinjiang factory involved in coercive labor," Axios, June 29, 2020, https://www.axios.com/caterpillar-xinjiang-uighur-labor-a6ec73dfb75e-4aea-ae76-cc8182ad6a3c.html.

41 Peggy Sito, "Esquel Group, garment supplier to Tommy Hilfiger and Nike, says it's seeking to overturn US sanction on its Xinjiang plant," South China Morning Post, July 21, 2020, https://www.scmp.com/business/article/3094073/ esquel-group-garment-supplier-tommy-hilfiger-and-nike-says-its-seeking; "Divestment of Xinjiang White Field Farming Co. Ltd.," Esquel Group, May 13, 2020, https://www.esquel.com/news/divestment-xinjiang-white-field-farming-co-Itd.

42 Danielle Cave, Fergus Ryan, and Vicky Xiuzhong Xu, "Mapping more of China's tech giants: Al and surveillance," (Barton, Australia: Australian Strategic Policy Institute, November 28, 2019), https://www.aspi.org.au/report/ mapping-more-chinas-tech-giants; Dahlia Peterson and Josh Rudolph, "Sharper Eyes: Shandong to Xinjiang," China Digital Times, September 13, 2019, https://chinadigitaltimes.net/2019/09/sharper-eyes-shandong-to-xinjiangpart-3.

43 Darren Byler, “The Global Implications of ‘Re-education' Technologies in Northwest China,” (Washington, DC: Center for Global Policy, June 8, 2020), https://cgpolicy.org/articles/the-global-implications-of-re-educationtechnologies-in-northwest-china; Danielle Cave, Fergus Ryan, and Vicky Xiuzhong Xu, "Mapping more of China's tech giants."

44 Placement on the Entity List means companies are subject to additional license requirements and limited availability of most license exceptions for exports, reexports, and in-country transfers to entities on the list. See "Addition of Certain Entities to the Entity List," Federal Register, October 9, 2019, https://www.federalregister.gov/ documents/2019/10/09/2019-22210/addition-of-certain-entities-to-the-entity-list; Amy K. Lehr and Efthimia Maria ("Mariefaye”) Bechrakis, "The United States Blacklisted 28 Chinese Entities over Repression of Muslim Minorities in Xinjiang. What Does This Mean for Human Rights?" Center for Strategic and International Studies, October 11, 2019, https://www.csis.org/analysis/united-states-blacklisted-28-chinese-entities-over-repression-muslim-minoritiesxinjiang.

45 "Addition of Certain Entities to the Entity List," Federal Register.

46 AFP, "China's blacklisted Al firms: what you should know," Bangkok Post, October 13, 2019, https://www. bangkokpost.com/business/1771179/chinas-blacklisted-ai-firms-what-you-should-know. 
47 "Commerce Department to Add Nine Chinese Entities Related to Human Rights Abuses in the Xinjiang Uighur Autonomous Region to the Entity List," U.S. Department of Commerce, May 22, 2020, https://www.commerce. gov/news/press-releases/2020/05/commerce-department-add-nine-chinese-entities-related-human-rights.

48 "Commerce Department to Add Nine Chinese Entities Related to Human Rights Abuses in the Xinjiang Uighur Autonomous Region to the Entity List," U.S. Department of Commerce; Simon Glover, "BCl slammed for refusing to quit Xinjiang," EcoTextile News, January 29, 2020, https://www.ecotextile.com/2020012925609/materialsproduction-news/bci-slammed-for-refusing-to-quit-xinjiang.html.

49 The national team was first launched in November 2017 with five members, and has since expanded to 15 total. See Jeffrey Ding, "China's Al “National Team," ChinAl, May 20, 2019, https://chinai.substack.com/p/ chinai-51-chinas-ai-national-team; “科技部扩容“Al国家队'名单，十家新公司入选” [The Ministry of Science and Technology expands the list of 'Al National Team,' 10 new companies are selected], 电子工程专辑 [EE Times China], August 30, 2019, https://www.eet-china.com/news/201908301010.html.

50 Gregory C. Allen, “Understanding China's Al Strategy” (Washington, DC: Center for a New American Security, February 6, 2019), https://www.cnas.org/publications/reports/understanding-chinas-ai-strategy.

51 Charles Rollet, "In China's Far West, Companies Cash in on Surveillance Program That Targets Muslims," Foreign Policy, June 13, 2018, https://foreignpolicy.com/2018/06/13/in-chinas-far-west-companies-cash-in-onsurveillance-program-that-targets-muslims.

52 A big contributor to the discrepancy between Hikvision and Dahua's shares of the $\$ 1.2$ billion is Dahua winning the $\$ 686$ million Safe County project for Yarkant County, the location of the July 2014 rioting. See Charles Rollet, "Dahua and Hikvision Win Over \$1 Billion In Government-Backed Projects In Xinjiang," IPVM, April 23, 2018, https://ipvm.com/reports/xinjiang-dahua-hikvision.

53 Charles Rollet, "In China's Far West, Companies Cash in on Surveillance Program That Targets Muslims."

54 Charles Rollet, "Evidence Of Hikvision's Involvement With Xinjiang IJOP And Re-Education Camps," IPVM, October 2, 2018, https://ipvm.com/reports/hikvision-xinjiang.

55 “Hikvision: PRC Government “Exert Significant Influence Over Our Business,'” IPVM, March 28, 2018, https://ipvm.com/reports/hikvision-influence.

56 Charles Rollet, “Evidence Of Hikvision's Involvement With Xinjiang IJOP And Re-Education Camps”; "How Mass Surveillance Works in Xinjiang, China," Human Rights Watch, May 2, 2019, https://www.hrw.org/videophotos/interactive/2019/05/02/china-how-mass-surveillance-works-xinjiang; The CETC subsidiary, Hebei Far East Communication System Engineering Company, and 16 other entities tied to CETC had already been placed on the Entity List in August 2018 for "illicit procurement of commodities and technologies for unauthorized military end-use in China." See "Addition of Certain Entities; and Modification of Entry on the Entity List," Federal Register, August 1, 2018, https://www.federalregister.gov/documents/2018/08/01/2018-16474/addition-ofcertain-entities-and-modification-of-entry-on-the-entity-list.

57 Charles Rollet, “Evidence Of Hikvision's Involvement With Xinjiang IJOP and Re-Education Camps.”

58 The expos were the 4th China-Asia-Europe Security Expo and the 13th Xinjiang Police Anti-Terrorism Technical Equipment Expo. See “共筑平安新疆 云从科技携人脸识别亮相亚欧安防展览会” [Building safety in Xinjiang: CloudWalk Technology debuts face recognition at the Asia-Europe Security Exhibition], CTI Forum, August 24, 2017, https://web.archive.org/web/20200623203839/http://www.ctiforum.com/news/ guonei/519237.html; “商汤、旷视、云从、依图，究竟谁将在人脸识别领域独领风骚?” [Sensetime, Megvii, Cloudwalk, Yitu, who will be the leader in face recognition?], 新鲜事研究社 [What's New Research], May 19, 2013, https://web.archive.org/web/20200623212409/https://baijiahao.baidu.com/s?id=163341456583246 3606\&wfr=spider\&for $=$ pc. 
59 “云天励飞“深目”动态人像识别解决方案将亮相亚欧安博会” [Intellifusion's “Deep Eye’ Dynamic Portrait Recognition Solution Will Debut at Asia-Europe Expo], 中国安防展览网 [China Security Exhibition Network], August 8, 2017, https://archive.vn/OZkfO.

60 Cao Yiqing, “从依图科技看中国A的弯道超越” [Seeing the Acceleration of Chinese Al from Yitu Technology's Perspective], Yu De, October 11, 2019, https://web.archive.org/web/20200623212059/https:// baijiahao.baidu.com/s?id=1647058344062254767\&wfr=spider\&for=pc.

61 The "focus personnel" label is likely similar to the seven groups of "focus personnel" highlighted by Human Rights Watch: petitioners, those who "undermine stability," those who are involved in terrorism, major criminals, those involved with drugs, wanted persons, and those with mental health problems who "tend to cause disturbances." See "China: Police 'Big Data' Systems Violate Privacy, Target Dissent," Human Rights Watch, November 19, 2017, https://www.hrw.org/news/2017/11/19/china-police-big-data-systems-violate-privacytarget-dissent.

62 Darren Byler, "The Global Implications of 'Re-education' Technologies in Northwest China”; Meiya Pico was also responsible for the intrusive spying app MFSocket. Celia Chen and Meng Jing, "What you need to know about Meiya Pico, China's low-profile forensics champion named in data privacy scandal," South China Morning Post, July 9, 2019, https://www.scmp.com/tech/start-ups/article/3017688/what-you-need-know-about-meiyapico-chinas-low-profile-forensics.

63 Danielle Cave, Fergus Ryan, and Vicky Xiuzhong Xu, "Mapping more of China's tech giants."

64 “实体清单”事项 海康威视、大华股份最新、全面回应” [Hikvision, Dahua share their latest and comprehensive response to the 'Entity List'], 中国安防行业网 [China Security Industry Network], October 10, 2019, https://web.archive.org/web/20200623220513/http://news.21csp.com.cn/c34/201910/11389485. $\underline{\mathrm{html}}$.

65 Jane Zhang, "China's Al champions are already powering a mind-boggling array of processes and this will rise in 2020," South China Morning Post, January 1, 2020, https://www.scmp.com/tech/start-ups/ article/3044188/chinas-ai-champions-are-already-powering-mind-boggling-array.

66 "Divestment of Xinjiang White Field Farming Co. Ltd.," Esquel Group. Increased scrutiny on Esquel's exports of U.S. technology might endanger the company's access to robotics, a strategic direction the company has announced. Ryan Swift, "Hong Kong shirtmaker Esquel turns to robots to beat US tariffs," South China Morning Post, September 25, 2018, https://www.scmp.com/business/banking-finance/article/2165582/hong-kongshirtmaker-esquel-turns-robots-beat-us-tariffs.

67 Ryan Swift, "Hong Kong shirtmaker Esquel turns to robots to beat US tariffs."

68 This includes one of the 11 Dahua and Hikvision Xinjiang projects highlighted by IPVM worth \$1.2 billion. Leon was one of the awardees alongside Dahua in the Qiemo Safe County project in 2017. See Charles Rollet, "Dahua and Hikvision Win Over \$1 Billion In Government-Backed Projects In Xinjiang"; Jeffrey Ding, "Complicit - China's AI Unicorns and the Securitization of Xinjiang," ChinAl, September 23, 2018, https://chinai.substack. $\mathrm{com} / \mathrm{p} /$ chinai-newsletter-29-complicit-chinas-ai-unicorns-and-the-securitization-of-xinjiang.

69 Jeffrey Ding, “Complicit - China's Al Unicorns and the Securitization of Xinjiang."

70 Masha Borak, “China's 'data doors' scoop up information straight from your phone," South China Morning Post, May 7, 2019, https://www.scmp.com/abacus/tech/article/3029333/chinas-data-doors-scoopinformation-straight-your-phone.

71 Ibid. 
72 Ibid.

73 For more on how Thermo Fisher enabled biometric surveillance in China, see Sui-Lee Wee, "China is Collecting DNA from Tens of Millions of Men and Boys, Using U.S. Equipment," The New York Times, June 17, 2020, https://www.nytimes.com/2020/06/17/world/asia/China-DNA-surveillance.html.

74 These hardware solutions include GPUs and FPGAs. See Lorand Laskai and Helen Toner, "Can China Grow Its Own Al Tech Base?," New America, November 4, 2019, https://www.newamerica.org/cybersecurity-initiative/ digichina/blog/can-china-grow-its-own-ai-tech-base.

75 Xilinx provides chips called FPGAs, while Seagate and Western Digital provide Al surveillance-optimized storage solutions. For further details see Dahlia Peterson, "Foreign Technology and the Surveillance State" in China's Quest for Foreign Technology: Beyond Espionage, eds. William C. Hannas and Didi Kirsten Tatlow (London: Routledge, September 2020).

76 “Al芯片厂商与传统安防制造企业紧密合作 拓展安防业务” [Al chip manufacturers work closely with traditional security manufacturing companies to expand security business], 中国安防行业网 [China Security Industry Network], December 28, 2017, https://web.archive.org/web/20200630000620/http://news.21csp. com.cn/c34/201712/11365694.html.

77 For further examples see Dahlia Peterson, "Foreign Technology and the Surveillance State."

78 “Congressional Letter Calls Out US Companies Supporting Dahua and Hikvision," IPVM, March 11, 2019, https://ipvm.com/reports/letter-support; Liza Lin and Josh Chin, "U.S. Tech Companies Prop Up China's Vast Surveillance Network," The Wall Street Journal, November 26, 2019, https://www.wsj.com/articles/u-s-techcompanies-prop-up-chinas-vast-surveillance-network-11574786846.

79 “China Uyghur Analytic Projects Require Intel And NVIDIA, Intel Condemns, NVIDIA Silent," IPVM, December 2, 2019, https://ipvm.com/reports/uyghur-intel-nvidia.

80 Charles Rollet, “China Government Spreads Uyghur Analytics Across China," IPVM, November 25, 2019, https://ipvm.com/reports/ethnicity-analytics; Paul Mozur, "One Month, 500,000 Face Scans: How China Is Using A.I. to Profile a Minority," The New York Times, April 14, 2019, https://www.nytimes.com/2019/04/14/ technology/china-surveillance-artificial-intelligence-racial-profiling.html. Hikvision is a notable example of a company that actively marketed - then deleted - coverage of its Uyghur detection and analytics capabilities on its website. See Charles Rollet, "Hikvision Markets Uyghur Ethnicity Analytics, Now Covers Up," IPVM, November 11, 2019, https://ipvm.com/reports/hikvision-uyghur.

81 Matt Schiavenza, “Why Aren't More Countries Confronting China over Xinjiang?," ChinaFile, January 14, 2020, https://www.chinafile.com/reporting-opinion/viewpoint/why-arent-more-countries-confronting-china-overxinjiang. Qatar initially signed, then withdrew its support for the UNHCR letter deploring the Xinjiang situation.

82 “Inter-Parliamentary Alliance on China," Inter-Parliamentary Alliance on China, https://www.ipac.global; Benedict Rogers, "Parliamentarians From Around the World Unite to Discuss the China Challenge," The Diplomat, June 6, 2020, https://thediplomat.com/2020/06/parliamentarians-from-around-the-world-unite-to-discuss-thechina-challenge; "Launch of the Global Partnership on Artificial Intelligence by 15 founding members," French Ministry for Europe and Foreign Affairs, June 15, 2020, https://www.diplomatie.gouv.fr/en/french-foreign-policy/ digital-diplomacy/news/article/launch-of-the-global-partnership-on-artificial-intelligence-by-15-founding.

83 Anna Gross and Madhumita Murgia, "China Shows its Dominance in Surveillance Technology," Financial Times, December 26, 2019, https://www.ft.com/content/b34d8ff8-21b4-11ea-92da-f0c92e957a96. 
84 California Office of Environmental Health Hazard Assessment, "The Proposition 65 List," https://oehha.ca.gov/ proposition-65/proposition-65-list; United States Environmental Protection Agency, "Toxics Release Inventory (TRI) Program," https://www.epa.gov/toxics-release-inventory-tri-program.

85 Danielle Cave, Fergus Ryan, and Vicky Xiuzhong Xu, “Mapping more of China’s tech giants."

86 The guidance says "Before a transaction, Exporters should consider what the Item is capable of, and how it could be used or misused by authorities. Exporters might consider integrating safety and 'privacy by design' features that enable them to track the Item's deployment and alert them to misuse, strip certain capabilities from the Item, auto-delete data and provide a kill-switch." See "Draft U.S. Government Guidance for the Export of Hardware, Software and Technology With Surveillance Capabilities and/or Parts/Know-how," U.S. Department of State, October 29, 2019, https://www.eff.org/files/2019/10/29/draft-guidance-for-the-export-of-hardware-software-andtechnology-with-surveillance-capabilities.pdf.

87 The Wassenaar Arrangement, https://www.wassenaar.org/.

88 Foreign Advanced Technology Surveillance Accountability Act, H.R. 7307, 116th Cong. (2020), https://www. congress.gov/bill/116th-congress/house-bill/7307/text; "Curtis, Malinowski Introduce Bipartisan Foreign Advanced Technology Surveillance Accountability Act," Congressman John Curtis, June 24, 2020, https://curtis.house.gov/ press-releases/curtis-malinowski-introduce-bipartisan-foreign-advanced-technology-surveillance-accountability-act.

89 Danielle Cave, Fergus Ryan, and Vicky Xiuzhong Xu, “Mapping more of China’s tech giants.”

90 James T. Areddy and Michelle Hackman, "China's Muslim Uighurs Are Stuck in U.S. Immigration Limbo," The Wall Street Journal, July 28, 2020, https://www.wsj.com/articles/chinas-muslim-uighurs-are-stuck-in-u-simmigration-limbo-11595937603.

91 Involuntary labor related to Xinjiang oppression is complex and pervasive, occurring well beyond factories located within or adjacent to internment camps. The U.S. Tariff Act of 1930 defines "forced labor" as "all work or service which is exacted from any person under the menace of any penalty for its nonperformance and for which the worker does not offer himself voluntarily." This could potentially include all Uyghurs and others channeled into state-run and public-private manufacturing arrangements in a context when refusal may result in internment or imprisonment. Tariff Act of 1930, 19 U.S.C. $\$ 1307$ (1930), https://uscode.house.gov/view.xhtml?path=/prelim@ title19/chapter4\&edition=prelim.

92 Jason Judd and Sarosh Kuruvilla, "Why apparel brands' efforts to police their supply chains aren't working," The Conversation, April 30, 2020. https://theconversation.com/why-apparel-brands-efforts-to-police-their-supplychains-arent-working-136821.

93 Bethany Allen-Ebrahimian, "Exclusive: Caterpillar sourced clothes from Xinjiang factory involved in coercive labor."

94 Amy Lehr, "Addressing Forced Labor in the Xinjiang Uyghur Autonomous Region."

95 Uyghur Human Rights Policy Act of 2020, Pub. L. No. 116-145 (2020) https://www.congress.gov/116/plaws/ publ145/PLAW-116publ145.pdf.

96 See “Meshrep," Intangible Cultural Heritage, United Nations Educational, Scientific and Cultural Organization, https://ich.unesco.org/en/USL/meshrep-00304 and “Uyghur Muqam of Xinjiang," Intangible Cultural Heritage, United Nations Educational, Scientific and Cultural Organization, https://ich.unesco.org/en/RL/uyghur-muqamof-xinjiang-00109. For background on abuses of these and other Uyghur cultural heritage, see "UHRP Report: Extracting Cultural Resources: the Exploitation and Criminalization of Uyghur Cultural Heritage," (Washington, DC: Uyghur Human Rights Project, June 12, 2018), https://uhrp.org/press-release/extracting-cultural-resourcesexploitation-and-criminalization-uyghur-cultural. 
97 Minxin Pei, "China needs an exit strategy from Xinjiang," Nikkei Asian Review, August 8, 2020, https://asia. nikkei.com/Opinion/China-needs-an-exit-strategy-from-Xinjiang2; Amy Lehr, "Addressing Forced Labor in the Xinjiang Uyghur Autonomous Region." Ilham Tohti, "Present-Day Ethnic Problems in Xinjiang Uighur Autonomous Region" and other writing by Tohti and other Chinese social scientists have proposed models for Xinjiang development that would avoid the mistakes of both the Pairing Assistance Program and the Great Development of the West campaigns. 


\section{ABOUT THE AUTHORS}

James Millward is a professor of history at the Walsh School of Foreign Service at Georgetown University, where he teaches Chinese, Central Asian, and world history. He also teaches as visiting faculty in the Máster Oficial en Estudios de Asia Oriental at the University of Granada in Spain. His specialties include the Qing empire, the silk road, and historical and contemporary Xinjiang. Millward is the author of Eurasian Crossroads: A History of Xinjiang (second edition forthcoming in 2020 with Hurst).

Dahlia Peterson is a research analyst at Georgetown's Center for Security and Emerging Technology (CSET). She researches China's use of predictive policing algorithms and facial, voice, and gait recognition technologies for its Al-powered surveillance programs, how Western companies contribute to Chinese surveillance, and how to safeguard the U.S. from threats to its research enterprise. She previously interned for the U.S.-China Economic and Security Review Commission (USCC), the State Department's Virtual Student Federal Service, and the Foreign Commercial Service at the U.S. Embassy in Beijing. Peterson holds a B.A. in Economics and Chinese Language with a minor in China Studies from the University of California, Berkeley (Phi Beta Kappa), and is pursuing a masters at Georgetown University's Security Studies Program.

\section{ACKNOWLEDGEMENTS}

The authors would like to thank Julian Gewirtz for helpful discussions, Igor Mikolic-Torreira, Lynne Weil, and Remco Zwetsloot for editing assistance, and anonymous peer reviewers for comments on the draft. Ted Reinert edited this paper, and Rachel Slattery provided layout.

\section{Document Identifier: doi: 10.51593/20200017}

The Brookings Institution is a nonprofit organization devoted to independent research and policy solutions. Its mission is to conduct high-quality, independent research and, based on that research, to provide innovative, practical recommendations for policymakers and the public. The conclusions and recommendations of any Brookings publication are solely those of its author(s), and do not reflect the views of the Institution, its management, or its other scholars. 